Trinity College

Trinity College Digital Repository

Faculty Scholarship

$12-2003$

T. S. Eliot and the Lost Youth of Modern Poetry

David Rosen

Trinity College, david.rosen@trincoll.edu

Follow this and additional works at: https://digitalrepository.trincoll.edu/facpub

Part of the Modern Literature Commons 


\title{
T. S. Eliot and the Lost Youth of Modern Poetry
}

\author{
David Rosen
}

There she was (my Lolita!), hopelessly worn at seventeen._-Vladimir Nabokov

\begin{abstract}
$\mathrm{M}$ odern poetry was never young. In 1913 or thereabouts W. B. Yeats, fifty years a youth, declared himself an old man, and thereupon was recognized as a kindred spirit by Ezra Pound. In that same year Robert Frost published his first book of verse at the advanced age of thirty-nine. Within the next twelve months T. S. Eliot arrived in England from America, still in his mid-twenties yet toting a manuscript of poems, many begun much earlier, about fading old ladies and anxious aesthetes. This is one of the earliest:
\end{abstract}

Convictions (Curtain Raiser)

Among my marionettes I find

The enthusiasm is intense!

They see the outlines of their stage

Conceived upon a scale immense

And even in this later age

Await an audience open-mouthed

At climax and suspense.

Two, in a garden scene

Go picking paper roses;

Hero and heroine, alone,

The monotone

Of promises and compliments

And guesses and supposes.

And over there my Paladins

Are talking of effect and cause,

With "learn to live by nature's laws!"

And "strive for social happiness 
And contact with your fellow-men

In Reason: nothing to excess!"

As one leaves off the next begins.

And one, a lady with a fan

Cries to her waiting-maid discreet

"Where shall I ever find the man!

One who appreciates my soul;

I'd throw my heart beneath his feet.

I'd give my life to his control."

(With more that I shall not repeat.)

My marionettes (or so they say)

Have these keen moments every day. ${ }^{1}$

The speaking voice is manifestly one of experience or, at least, manifestly wishes to seem experienced. It is a voice whose knowledge of history ("this later age") has enabled it to see through the passing enthusiasms of the present. It uses archaisms syntactic ("scale immense") and generic ("a lady with a fan ... her waiting-maid discreet"). It evokes, finally, a public whose very excitement ("open-mouthed") only further implies the speaker's own wisdom and maturity. As it happens, the internal evidence is misleading: when Eliot wrote this poem, he was barely twenty-two. That he should have felt it necessary, even desirable, to assume such a tone suggests a deeper problem in the psychology of modern lyric, with broad consequences in poetic form and ideology.

My reading of Eliot's career through The Waste Land has for its background the late-nineteenth-century crisis in imaginative lyric, specifically the strain of ecstatic, oracular poetry, descending via late Wordsworth and Coleridge, through Shelley, to Swinburne and early Yeats, that had finally spent itself (some late, solitary eruptions like Crane and Lawrence notwithstanding) by 1900 . This dissolution resulted from a nexus of external and internal tensions, all coming to a head in the 189os. The external causes are familiar from other histories of the rise

1 T. S. Eliot, Inventions of the March Hare: Poems, I909-I9I7, ed. Christopher Ricks (New York: Harcourt Brace, 1996), 11. Hereafter cited as $M H$.

David Rosen is assistant professor of English at Trinity College. He is completing a book on modern poetry and plain language. 
of modernism: social and intellectual developments that both altered the cultural status of literature generally and opened new forms of expression for it to pursue. ${ }^{2}$ The internal developments, however, were endemic to imaginative lyric alone.

"Every man has his speculations," John Keats commented, "but every man does not brood and peacock over them till he makes a false coinage and deceives himself."3 The claims of imaginative poetry after Wordsworth were dependent on an understanding of self that seemed less and less tenable as Romanticism receded. In the "Intimations Ode" Wordsworth had famously interpreted the amnesic voids in his history as the signs of a creative or visionary capacity within. The unknowable was in fact powerful and transcendent. If Keats was alone among his contemporaries in detecting bad faith in Wordsworth's psychology, such unease was widespread by century's end. ${ }^{4}$ Yeats's career after 1913, the year he published Responsibilities and began his memoirs, may be

2 On "high" modernism as a reaction by social and intellectual elites against an insurgent mass culture see Andreas Huyssen, After the Great Divide: Modernism, Mass Culture, Postmodernism (Bloomington: Indiana University Press, 1986), esp. "The Hidden Dialectic: Avant-Garde - Technology-Mass Culture" (3-15) and "Mass Culture As Woman: Modernism's Other" (44-62). See also John Carey, The Intellectuals and the Masses: Pride and Prejudice among the Literary Intelligentsia, I880-1939 (London: Faber and Faber, 1992); Fredric Jameson, The Political Unconscious: Narrative As a Socially Symbolic Act (Ithaca, N.Y.: Cornell University Press, 1981); and Jameson, Fables of Aggression: Wyndham Lewis, the Modernist As Fascist (Berkeley: University of California Press, 1979), esp. "The Jaundiced Eye" (122-35). Raymond Williams treats modernism as a larger cultural phenomenon linked to late-nineteenthcentury urbanism in The Country and the City (New York: Oxford University Press, 1973), 215-307. For important studies tracing the origins of modernism in nineteenthcentury philosophy see Michael H. Levenson, A Genealogy of Modernism: A Study of English Literary Doctrine, 1908-1922 (Cambridge: Cambridge University Press, 1984); Judith Ryan, The Vanishing Subject: Early Psychology and Literary Modernism (Chicago: University of Chicago Press, 1991); and Frank Lentricchia, Modernist Quartet (Cambridge: Cambridge University Press, 1994).

${ }^{3}$ Keats to J. H. Reynolds, 3 February 1818, in Letters of John Keats: A New Selection, ed. Robert Gittings (London: Oxford University Press, 1970), 60.

${ }^{4}$ See Charles Altieri, Painterly Abstraction in Modernist American Poetry: The Contemporaneity of Modernism (Cambridge: Cambridge University Press, 1989), 3-7. Altieri discusses a late Victorian "crisis of recommendation," in which Romantic claims to a "radical subjectivity" were inevitably ironized by a counter ideal "of intellectual judgement [which required] it to treat all human actions as if they were subject to exhaustive third person descriptions." High modern abstraction emerged as a strategy for circumventing this subjective-objective bind. 
understood as an attempt to recoup an oracular authority for his poetry after losing all faith in the psychology that justified such authority. Although this attempt produced the great works of his late career, his achievement - which I use here as a foil to Eliot's—was idiosyncratic; even among poets equally interested in preserving for poetry a privileged place among the literary genres, Yeats's complex synthesis of autobiography and race memory, national and personal mythologies, hermeticism and polemic, attracted few followers. The great majority followed a trail blazed by Eliot.

As we return to "Convictions," let us consider also the following two stanzas:

Great duties call-the twentieth century

More grandly dowered than those which came before,

Summons - who knows what time may hold in store,

Or what great deeds the distant years may see,

What conquest over pain and misery,

What heroes greater than were e'er of yore!...

As thou to thy departing sons hast been

To those that follow may'st thou be no less;

A guide to warn them, and a friend to bless

Before they leave thy care for lands unseen;

And let thy motto be, proud and serene,

Still as the years pass by, the word "Progress!"

Neither this poem nor "Convictions," for obvious reasons, made it into Eliot's official canon. These stanzas are excerpted from a much longer piece Eliot wrote for his high school graduation (1905), while "Convictions" (1910) appears in a substantial manuscript of early poems, most dating from his time at Harvard University, that finally appeared in 1996 as Inventions of the March Hare. Although Eliot in 1905 was not yet a formed talent, his transformation, radically rethinking his style and outlook and rejecting an established kind of lyric, was nevertheless spectacular: a genteel doggerel fit for the magazine and parlor (or, in this case, the rostrum); then, only a few years later, an edgy, more selfaware verse bristling with contempt for gentility. Boilerplate stanzas give

${ }^{5}$ T. S. Eliot, "At Graduation, 1905," in Poems Written in Early Youth, ed. Valerie Eliot (New York: Farrar, Straus and Giroux, 1967), 13, 17. Hereafter cited as PEY. 
way to rhymes whose banality is part of the satiric point. Even in the graduation poem it is clear that Eliot has no plans to stick around St. Louis ("We shall desire to see again the spot / . . . [when] to distant lands we may have gone" $[P E Y, 14])$; yet, judging by his expansive tone there, the young man seems destined to go west ("Progress!"). In "Convictions" progress, like most other bourgeois totems ("nature's laws," "social happiness," "Reason"), is dismissed in an audibly Gallic accent.

It is not hard to extrapolate from the Harvard lyric the reasons for Eliot's geographic U-turn. The poem suggests a person suddenly perceiving himself as provincial and trying to compensate with a sophistication that does not yet feel genuine. ${ }^{6}$ The third and fourth stanzas have a shrillness that Eliot is later able to contain, or put to better use. As one might expect, the turn against origins is also a turn against class. His mandarins, empty-headed puppets enacting the clichés of uppermiddle-class life, are only slightly better off than their "audience," an urban proletariat gawking at them open-mouthed. ${ }^{7}$ Eliot, at a further remove, can look down on both. One might infer, finally, a more personal perplexity: where Eliot's earliest phase included banal romantic verse ("the wild roses in your wreath / Were faded, and the leaves were brown" ["Song," PEY, 22]), he shows now, in his "lady with a fan" and his monotonal couple, the first traces of his characteristic misogyny and erotic despair.

In short, if we correct for differences in age and local color, we may perceive strong similarities between Eliot at twenty-two and Yeats at roughly the same time, 1900-1910, a decade of personal and professional crisis during which Yeats abandoned the symbolist premises that had sustained his early career. There is, first, a similar choice of antagonisms: "paper roses," Eliot's image for the vulgarity of the nouveaux riches, has the same motive as Yeats's sneer about "new commonness . . .

${ }^{6}$ On Eliot's arrival at Harvard see Lyndall Gordon, Eliot's Early Years (Oxford: Oxford University Press, 1977), 15-36. See also Robert Crawford, Devolving English Literature, 2d ed. (Edinburgh: Edinburgh University Press, 2000), 216-71. According to Crawford, Eliot's provincialism was almost wholly beneficial: it allowed him a vantage point simultaneously outside and inside the sophisticated culture of Boston (and later London). The hybrid nature of his poetry, at once "primitive" and "cosmopolitan," is an outgrowth of this position.

7 See Eric Sigg, The American T. S. Eliot: A Study of the Early Writing (Cambridge: Cambridge University Press, 1989), 110-24. 
hanging its paper flowers from post to post." 8 More fundamentally, Eliot shows a similar rejection of self and of personal memory, implicit in the rejection of origins, that necessitates a reestablishment of poetic identity on new terms. Developmental psychology, which seeks to root identity not in ancestry, nation, or culture but entirely in personal history, is more dangerous a middle-class failing than mere philistinism. ${ }^{9}$ Not surprising, the purged voice feels unmoored. "Convictions" is a satiric title, yet the speaker offers no obvious alternative to the values he attacks. Both Eliot's repeated use of the possessive ("my marionettes," "my Paladins") and his main conceit (a puppet theater) suggest some control over, or fascination with, a situation from which, in all other respects, he seems detached or estranged. The sense of a self is so weak that, for large stretches of the March Hare manuscript, the first-person singular pronoun disappears altogether.

In poem after poem, each clearly spoken by a solitary narrator, Eliot resorts to the plural, or to the second person, as if his speakers required the support of imagined companions to be heard at all:

We turn the corner of the street...

("Fourth Caprice in Montparnasse," MH, 14)

We hibernate among the bricks ...

("Interlude in London," $M H, 16$ )

It's utterly illogical

Our making such a start, indeed

And thinking that we must return ...

("Embarquement pour Cythère," MH, 27)

It is a tic familiar from Eliot's early official work as well: the "Preludes," "Rhapsody on a Windy Night," the end of "Prufrock." Indeed, he ventures to use the $I$ by itself only in dramatic monologues, like the "Por-

8 The Collected Poems of W. B. Yeats, ed. Richard J. Finneran, 2d ed. (New York: Scribner, 1996), 77 .

9 For a contrasting discussion of modernism's hostility to psychology see Martin Jay, "Modernism and the Spectre of Psychologism," Modernism/Modernity 3 (1996): 93-108. Where I see the modernists' hostility emerging from feelings of social vulnerability, Jay detects a philosophical discomfort: psychology, by concentrating on the "historical," individual mind, was inevitably relativistic. The modernists, in his account, sought refuge in philosophical objectivity. 
trait of a Lady," or (a curiosity I will examine shortly) to describe feelings of terror:

The seas of experience

That were so broad and deep,

So immediate and steep,

Are suddenly still.

You may say what you will,

At such peace I am terrified.

There is nothing else beside.

("Silence," $M H, 18$ )

And in short, I was afraid. ${ }^{10}$

It would be a mistake, however, to read the March Hare manuscript, on the analogy of Yeats, as evidence of a crisis in Eliot's career. For Yeats, the collapse of his early symbolist style is a disaster, and his late period, starting with Responsibilities, is forged in an attempt to overcome the despondency of 1900-1910. But the March Hare poems, for all their turmoil, have an undeniable vigor and feel like what they are: a beginning, not an end. The curtain, after all, is being raised.

A similar situation, very different responses. The distance between two positions is best measured from a third, in this case a book that Yeats and Eliot had in common. Arthur Symons's The Symbolist Movement in Literature (1899) is best known now for introducing English-speaking audiences to French writing of the late nineteenth century. Its influence on Eliot's generation, and on Eliot in particular, has long been acknowledged. He read the book while at college in 1908 and almost immediately began writing poems like "Convictions" (Gordon, 28-32; $M H, 103)$. This encounter is surely the clearest line of demarcation between Eliot's Harvard and high school styles. As an introduction to Verlaine, Rimbaud, and company, however, The Symbolist Movement in Literature is highly tendentious: dedicated to Yeats, with whom the author consulted closely while writing, it is, as much as anything, a primer in Yeats's early beliefs. The book's contempt for modernity, the "age of Science . . . and material things," is as typically Yeatsian as the accompanying association of art with the aristocratic and timeless: "To

10 T. S. Eliot, "The Love Song of J. Alfred Prufrock," in Complete Poems and Plays (New York: Harcourt Brace Jovanovich, 1952), 6. Hereafter cited as CPP. 
the aristocratic conception of things, nobility of soul is indeed a birthright, and the pride with which this gift of nature is accepted is a pride of exactly the opposite kind to that democratic pride to which nobility of soul is a conquest."11 More important, Symons's ontology bears his friend's imprint. The poetic symbol is understood to belong to a pool of eternal images, existing outside the self and glimpsed only in moments of ecstasy: "Vision, the overpowering vision . . . is the root out of which the flower must grow. . . . It is by symbol alone that the flower can take visible form" (SML, 20). Such mysticism takes a radically impersonal view of the imagination. The visionary moment: "The consciousness seems, as it were, to expand and contract at once, into something too wide for the universe, and too narrow for the thought of self to find room within it. Is it that the sense of identity is about to evaporate, annihilating all, or is it that a more profound identity, the identity of the whole sentient universe, has been realized?" (SML, 14).

"Talking of effect and cause": in the spirit of his Paladins, Eliot might be said to get Symons (intentionally) backward. He draws freely on Symons for points of style and technique; indeed, many of his March Hare poems, especially those with urban settings, could easily be mistaken for Symons's own work:

A street-piano, garrulous and frail;

The yellow evening flung against the panes

Of dirty windows: and the distant strains

Of children's voices, ended in a wail.

("First Caprice in North Cambridge," $M H, 13$ )

The dim wet pavement lit irregularly

With shimmering streaks of gaslight, faint and frayed,

Shone luminous green where sheets of glass displayed

Long breadths of faded blinds mechanically. ${ }^{12}$

Symons's sophistication, his immersion in modern city life, his skills as an observer, and his class snobbery had an inevitable appeal for the young Eliot. More important, Symons demonstrated that such a poetry

${ }^{11}$ Arthur Symons, The Symbolist Movement in Literature (New York: Dutton, 1958), 3, 22. Hereafter cited as $S M L$.

12 "A Winter Night," in The Collected Works of Arthur Symons, vol. 1 (London: Secker, 1924), 84 . 
could be written without recourse to personal history or emotions. The justification that he offered for such claims, however, his ontological account of the image, appealed to Eliot not a bit. Thus his salient difference from Yeats: when Yeats could no longer believe in symbolism, he sought and found other grounds on which to write ecstatic and oracular poetry. Eliot, never invested in the symbolist metaphysic, could suffer its downfall with equanimity, drawing on symbolist techniques and writing a poetry with no pretenses to vision (cf. Levenson, 8-10). Most modern poets, even those who differed from him and each other vastly in other respects, took the same course. From Wordsworth to Yeats, the faculty of mind at work in poetry is best called "imagination"; after Eliot, "consciousness."

Modern poetry after Eliot is a poetry of consciousness. Other critics, meaning something very different, have made similar-sounding declarations, so some clarification may be necessary. In particular, I must dissociate my argument from two influential accounts of the period. The first, in Hugh Underhill's concise paraphrase: "There is no identity which is not socio-historical, which is other than a cultural construction."13 To put it another way, consciousness may be understood as something transpersonal, an aspect of the larger culture, changing as the culture changes and operating through individuals, voluntarily or not. The West, in its modern phase, produces a distinctive modern consciousness, and modern artists, in turn, be they poets, painters, or novelists, may be evaluated for the ways that their work reflects or measures against this condition. That Eliot's poetry, which so often claims to speak to the modern plight, should lend itself readily to such evaluation is no surprise. More to the point, many critics of culture who offer this idea of consciousness (notably Raymond Williams; more recently, Underhill) are themselves operating out of a tradition - going back, via Leavis, to Arnold — in which Eliot himself, as prose writer, is a major figure. ${ }^{14}$ As he writes in a late essay, ostensibly about Yeats but clearly also about himself: "There

13 Hugh Underhill, The Problem of Consciousness in Modern Poetry (Cambridge: Cambridge University Press, 1992), 13.

${ }^{14}$ See Williams's discussion of modern urban consciousness in The Country and the City, 215-47. See also Williams, Culture and Society, I780-1950 (New York: Columbia University Press, $195^{8)}$, esp. "Marxism and Culture" (258-75). 
are [poets] whose poetry, though giving equally experience and delight, has a larger historical importance. Yeats was one of the latter: he was one of those few whose history is the history of their own time, who are a part of the consciousness of an age which cannot be understood apart from them."15 It is not my purpose to quarrel with this line of thought; my concerns, indeed, may be complementary to it. I am interested in consciousness not as a social construct (which, without contradiction, it may well be) but as an aspect of the individual mind, as, in Eliot's own phrase, "a mechanism of sensibility" $(S P, 64)$ conspicuous in both the subject matter and the substance of much modern writing. Modern writing, I emphasize: where cultural history takes consciousness to be an aspect of society in any period, my interest is in the way modern poets understood it as their own special problem.

Here I find myself in more fundamental disagreement with a second influential line of commentary. In accounts of the rise of modernism it is a commonplace to note the era's new interest in the solitary working human mind. ${ }^{16}$ Radical narrative techniques like free indirect discourse and interior monologue, the development of imagism, and the philosophical concern with subjectivity in Bergson and Husserl are all produced as evidence of this revolution. Within modest boundaries, such claims are inarguable. Michael H. Levenson, whose Genealogy of Modernism is probably the most visible history of these ideas, sees the late-nineteenth-century literary interest in consciousness, a "registering temperament which might endow 'passing events with their true meaning'" (4), as an outgrowth of mimetic fiction. ${ }^{17}$ Conrad, James, and other heirs to the realistic novel could explore the work of perception and motivation without the crude intermediary of an omniscient narrator. In Ford's tricky phrase, the novelist's task was to "produce an illusion of reality" by depicting the world as actually perceived; this impressionistic approach, he claimed, was an improvement on third-person

15 T. S. Eliot, "Yeats," in Selected Prose (New York: Farrar, Straus and Giroux, 1975), 257. Hereafter cited as SP.

${ }^{16}$ Ryan's The Vanishing Subject provides a useful history of this interest, tracing the influence of pre-Freudian, experimental psychology (Ernst Mach, William James) on a broad range of modernist techniques, notably interior monologue. The focus is on Continental (Hofmannsthal, Rilke) as well as English and American modernisms.

${ }^{17}$ Levenson is quoting Joseph Conrad's preface to The Nigger of the Narcissus (New York: Doubleday, Page, 1916), vii. 
description, however photographic or neutral it might seem. ${ }^{18}$ The history is then complicated by a series of conflicts: aestheticism, expressionism, imagism. While impressionism sank into the slough of solipsism, a point that Ford readily acknowledged, other writers - notably T. E. Hulme and Ezra Pound - pursued the grail of pure objectivity, an art untainted by the personality of its creator. These conflicts grew increasingly intricate, climaxed with high modernism, and, in Levenson's account, found some resolution in Eliot's poetry.

That British novelists and poets working between 1880 and 1930 had an interest in consciousness is not at issue, nor is it contentious to observe that Eliot was influenced by Conrad. One need only recall his epigrams or his numerous passages that sound lifted from The Secret Agent (e.g., "Streets that follow like a tedious argument / Of insidious intent" ["Prufrock," CPP, 3]). It is a danger inherent in theories of any period or movement, however, that significant and absolute differences be lost amid grander generalizations: our "genealogy" turns out to be multiple, and, despite sharing the royal name, one line is revealed to descend from the king's mistress and the court plumber. In modernism, the absolute difference was generic - poetry and prose - and the sticking point was indeed consciousness.

To begin, novelists and poets discovered this "problem" more than a generation apart from each other: by the time Eliot published Prufrock and Other Observations, James was dead and Conrad's best work was more than a decade behind him. We have seen already the reasons for this hiatus: just when novelists were embracing new psychological techniques as a way to extend and refine realism, influential poets, from Yeats to Symons to Swinburne, were radically turned against both psychological introspection and the representation of everyday life. Eliot, although an avid reader of English fiction, was, as a poet, heir to these men, and so, when consciousness made its delayed entry into verse, it was for motives vastly different from those behind the earlier prose.

More precisely, poets beginning especially with Wordsworth explained their careers by laying claim to an inner capacity that made them superior to - or at least different from — ordinary people: vision,

18 Critical Writings of Ford Madox Ford, ed. Frank MacShane (Lincoln: University of Nebraska Press, 1964), 43. See also Levenson, 107-8. 
imagination, and so on. Eliot made no attempt to salvage the visionary tradition after its collapse, but he did preserve a sense of poets' exceptionalism and had no plans to write merely conversational, "graceful verses" $(S P, 79)$. For this reason he could never, like the novelists before him, simply accept consciousness as the basis for a technique, or even as an interesting abstract problem to explore.$^{19}$ To catch the distinction, one need only consider Ford, who recognized no absolute difference between poetry and prose and who, as a poet, wrote precisely the "graceful verses" Eliot disdained (see Levenson, 111). Ford's achievement as a poet, Pound recognized, was in fact to bring to verse the rhythms and diction of prose. He also, however, brought a novelist's modesty. ${ }^{20}$ The impressionistic use of consciousness is tremendously effective and memorable in limning a character like John Dowell, yet when Ford writes poetry - in his own voice, as it were - the effect is nearly the opposite. Pound's assessment: "Mr. Ford brings to his work a prose training ... and it is absolutely the devil to try to quote snippets from a man whose poems are gracious impressions, leisurely, lowtoned" (374). Where Ford felt that a successful reader-author relation must be empathetic ("According to the measure of [an] artist's identity with his species, so will be the measure of his own greatness" [48]), Eliot, deeply committed to the special status of poetry but also aware that any high claims were vulnerable to ridicule, seized on consciousness as a badge of authority and distance.

To read Eliot otherwise would be to make him merely a novelist or philosopher in verse; this is the trap into which Levenson inevitably falls. Discussing The Waste Land, he writes: "No single consciousness presides; no single voice dominates. A character appears, looming suddenly into prominence, breaks into speech and then recedes, having bestowed momentary conscious perception on the scene" (172). And

${ }^{19}$ I am purposely avoiding the tendency to read Eliot's poetry as an extension of his philosophical work, in particular his dissertation on F. H. Bradley. I am doing so not because these links do not exist but because his concerns as a poet can easily be lost in the more abstract intellectual problems of his philosophy. For an account of his relation to Bradley see Hugh Kenner, "Bradley," in T. S. Eliot: A Collection of Critical Essays, ed. Hugh Kenner (Englewood Cliffs, N.J.: Prentice-Hall, 1962), 36-57.

20 "The Prose Tradition in Verse," in Literary Essays of Ezra Pound (New York: New Directions, 1935), 371-77. The essay was originally published in the June 1914 Poetry. 
where is Eliot? "The self, writes Eliot, 'passes from one point of view to another ...'; no single point of view is sufficient for knowledge; only in multiple perspectives does the world become real. . . Meaning is no longer identified with presence to an individual consciousness [but rather] is the product of multiple perspectives, 'of various presentations to various viewpoints'" (184). This distinction between "the self" and the multiple consciousnesses through which it passes, which are also somehow "presented" to it, is a semantic clouding of the issue: it just pushes back, by one term, the locus of poetic identity. It requires that one believe in Eliot's doctrine of impersonality, his idea of the poet standing magisterially outside his own creation and, conversely, of the artwork unsullied by the poet's narrow subjectivity, more than Eliot himself, acutely aware of the problems of lyric, ever could. ${ }^{21}$ Consciousness could not be, for him, a tool for the subtle investigation of character or of external reality. Rather, it was the faculty that, replacing imagination, made poets unique and that justified the otherwise absurd business of poetry writing.

Unfortunately, it was a faculty that, unlike the imagination, itself needed justifying. Neither creative nor likely to discover hermetic truths veiled from most mortals - unlikely, indeed, to differ in kind in a bard or a banker-consciousness had no obvious reason for being as the stuff and subject of poetry. The question on which Eliot's writing meditates between 1910 and 1927 is whether an individual consciousness, conceived in this way, can be a good in itself (see Underhill, 1-20).22 It is part of my argument that the official, published Eliot differs in no absolute way from the Eliot of the March Hare manuscript: although he becomes a more accomplished poet, and gladly allows his earlier poetry to languish, his verse and criticism through the mid-1920s are largely attempts to answer this question in the affirmative. The critical vocab-

${ }^{21}$ This is not to say that the belief is not widespread. In different ways, Jay, Levenson, Altieri, and Marjorie Perloff (see n. 29) accept the claims of Pound and Hulme (and later Olson, the objectivists, and the language poets) that such an untainted poetry (objective and abstract) is possible. I suspect that these claims were necessary emotionally for the modernists themselves but are precisely the sort of polemic that critics accept at their own risk.

22 Underhill's discussion of the "inward revolution" begins with Lawrence's assertion that "consciousness is an end in itself" (Apocalypse [London: Granada, 1981], 44). 
ulary he develops will be known to any undergraduate who, taking a modern poetry survey, has been exposed to the essays he wrote in these years. To be brief, then: in "The Metaphysical Poets" Eliot suggests that poets differ from everyone else in the sophistication and sensitivity of their consciousness; that is, they possess a "mechanism of sensibility [able to] devour any experience" $(S P, 64) .{ }^{23}$ This difference vindicates the claim that poets are thereby best fit to represent the consciousness of their society: "Our civilization comprehends great variety and complexity, and this variety and complexity, playing upon a refined sensibility, must produce various and complex results" $(S P, 65)$. The bestknown of Eliot's essays, "Tradition and the Individual Talent," takes this assertion to its logical extreme: poets are particularly aware of, and thus able to express, the larger societal consciousness, the "mind of Europe" $(S P, 39)$, as it has developed over the ages:

Tradition ... involves, in the first place, the historical sense, which we may call nearly indispensable to anyone who would continue to be a poet beyond his twenty-fifth year; and the historical sense involves a perception, not only of the pastness of the past, but of its presence; the historical sense compels a man to write not merely with his own generation in his bones, but with a feeling that the whole of the literature of Europe from Homer and within it the whole of the literature of his own country has a simultaneous existence and composes a simultaneous order. ... [It is] what makes a writer most acutely conscious of his place in time, of his own contemporaneity. $\left(S P, 3^{8}\right)$

I have passed over this much-debated material quickly and with little comment because it is only background to my main concern, the psychological implications of Eliot's position. As in philosophy or fiction, the poetic interest in consciousness, after Wordsworth, is tied up with questions of memory and identity, continuity in one being a basic test of the other (cf. Jay, 96-97). Not surprisingly, Eliot avoids these questions: the consciousness he describes is a floating awareness, infinitely susceptible, broad enough to include all of Western civilization but with no place for the personal past. "Emotion recollected in tranquility," he argues, controverting Wordsworth, "is an inexact formula": the substance of poetry

${ }^{23}$ Eliot is discussing John Donne, and only reflexively himself. 
is neither emotion, nor recollection, nor without distortion of meaning, tranquility. It is a concentration, and a new thing resulting from the concentration, of a very great number of experiences which to the practical and active person would not seem to be experiences at all. .. . These experiences are not "recollected," and they finally unite in an atmosphere which is "tranquil" only in that it is a passive attending upon the event. $(S P, 43)$

The consequence of this famous "escape from personality" $(S P, 43)$, however, is precisely the curiosity we observed at the start of this essay: Eliot's strenuous insistence on his own maturity, the poet disallowing any developmental or historical understanding of self and so needing simply to assert with sustained vehemence his own adultness and knowledge. Thus Yeats, suddenly an old man; thus Pound's declaration at thirty, "I have weathered the storm, / I have beaten out my exile";24 thus the next generation of modernists, Auden and his circle-the culmination of this phenomenon-hopelessly worn at seventeen; thus, in "Convictions," the peculiar spectacle of an undergraduate Eliot trying to sound world-weary.

In his criticism Eliot is typically sparing of praise, yet undoubtedly his most frequent term of approval, absorbed as if by osmosis by most critics of the period, is mature. The metaphysical poets are "more mature ... than later poets of certainly not less literary ability" (SP, $\left.6_{5}\right)$. France in 1600 "had already a more mature prose" than England (SP, 72 ). "If there is one word" that defines the term "“classic,' it is the word maturity" ( $S P, 116)$. As if speaking to his own condition (in a piece on Virgil), Eliot suggests that "maturity of mind, and the maturity of [one's] age, is exhibited in [an] awareness of history. With maturity of mind I have associated maturity of manners and [an] absence of provinciality" ( $S P, 123)$. And so on: the stridency of Eliot's assertions is directly proportional to the absence, in his poems, of psychological grounding for those assertions. ${ }^{25}$ Almost as a matter of course, the

24 "The Rest," in Selected Poems of Ezra Pound (New York: New Directions, 1956), 29-30.

${ }^{25}$ For a perceptive reading of Eliot in this mood see Richard Poirier, "The Difficulties of Modernism and the Modernism of Difficulty," in Critical Essays on American Modernism, ed. Michael J. Hoffman and Patrick D. Murphy (New York: Hall, 1992), $107-8$. 
Romantics, with their strong if often tacit psychological tensions, are dismissed as adolescent. ${ }^{26}$ Shelley, in particular, is merely an "intelligent and enthusiastic schoolboy," who attracts readers during that "intense period before maturity. . . . But for how many does Shelley remain the companion of age?" $(S P, 81)$. The Victorians, in turn, are lesser, superannuated Romantics, who had the misfortune to grow old without growing up. ${ }^{27}$ Tennyson, Eliot opines, "reached the end of his spiritual development with In Memoriam" (SP, 246). In a similar vein, he declares that "one gets the essential Browning or Swinburne entire in earlier poems; and in the later, one is reminded of the early freshness which they lack, without being made aware of any compensating new qualities. .. . Maturing as a poet means maturing as a whole man, experiencing new emotions appropriate to one's age, and with the same intensity as the emotions of youth" (SP, 249-5o). Perhaps the line from "Tithonus" to "Prufrock"- or, as we shall see shortly, "Gerontion"-is too direct for comfort; however gravely the Victorians "ruminated" ( $S P$, 65 ), they remained Romantic narcissists and never wrote successfully as older men. At all events, such value judgments are evident in Eliot's influential writing-off of the early, Shelley-worshipping Yeats and in his otherwise baffling, extravagant praise of the late Yeats as "pre-eminently the poet of middle age" ( $\left.S P, 25^{2}\right)$.

Although Yeats shared Eliot's hostility toward "that modish curiosity, psychology," his late work mimicked the psychological structure of Romantic lyric in interesting ways. ${ }^{28}$ For this reason, perhaps, he remained formally conservative to the end of his life. With Eliot and the poetry of consciousness, however, a new poetic morphology began to emerge. ${ }^{29}$ Consider the first verse paragraph of "Gerontion":

${ }^{26}$ One suspects that Eliot's attraction to the poetry of Jules Laforgue could only have been enhanced by Symons's calling him "the eternally grown up, mature to the point of self-negation" (61-62). Verlaine, a high Romantic "child" (54), would have had less appeal.

27 Levenson notes that certain modern novelists, among them Conrad and (especially) Ford, consciously adopted "childlike" poses to set themselves off from their "earnest" and "adult" Victorian predecessors $(56-59)$.

28 That is, by equating the world of visionary forms with the instinctual, Yeats preserved a tension between past (race memory) and present without bringing personal history into the equation. His dismissal of psychology as a "modish curiosity" may be found in Essays and Introductions (New York: Macmillan, 1961), 530.

${ }^{29}$ See Marjorie Perloff, "Postmodernism and the Impasse of Lyric," in The Dance 
Here I am, an old man in a dry month, Being read to by a boy, waiting for rain. I was neither at the hot gates Nor fought in the warm rain Nor knee deep in the salt marsh, heaving a cutlass, Bitten by flies, fought.

My house is a decayed house, And the jew squats on the window sill, the owner, Spawned in some estaminet of Antwerp, Blistered in Brussels, patched and peeled in London.

The goat coughs at night in the field overhead;

Rocks, moss, stonecrop, iron, merds.

The woman keeps the kitchen, makes tea, Sneezes at evening, poking the peevish gutter. I an old man,

A dull head among windy spaces.

$(C P P, 21)$

Where the imagination reflects and creates or, in moments of vision, perceives, the consciousness is recorded. As Eliot puts it, the mind's relation to experience is "a passive attending upon the event." 30 Indeed, in this poem the passivity is so pronounced that a blurring occurs between the speaker and the surrounding world. "Spawned . . . blistered ... patched and peeled": as the appositives pile up, it becomes increasingly difficult to determine their referent, the "little old man" of the title or his equally decrepit landlord. ${ }^{31}$ Where the imagination imposes on form a hierarchy of objects and occurrences (the kernel moment of vision, reflection on that moment, the wider context, etc.), consciousness merely happens and continues to happen until it stops. The Jewish landlord, a coughing goat, the woman who keeps the kitchen: with a peristaltic heave, each phrase seems to begin someplace very different from where the last left off, and in no obvious or inevitable

of the Intellect: Studies in the Poetry of the Pound Tradition (Evanston, Ill.: Northwestern University Press, 1985), 172-200. Where Perloff identifies some of these features as constituting a radical break from Romantic lyric (her central figure is Pound), I see their development in Eliot as continuous with Romantic questions of subjectivity.

${ }^{30}$ On Eliot's debt here to Bradley see Kenner, $42-44$.

31 The sense of self is weakened. I would not go so far as to claim that the subject disappears entirely. See Ryan (n. 2 above); and Levenson, 118. 
sequence. They could go on indefinitely. Consciousness, indeed, practically dictates an open form and thus the reemergent nonnarrative long poem. By the standard of Eliot's later work, not to mention that of the contemporaries whom he most influenced, from Stevens to Williams to Pound, "Gerontion," at three pages, is short. ${ }^{32}$

With Eliot, the denial of origins and of vision has inevitable consequences for language as well: no type of discourse is privileged over the others, neither the high, vatic style inherited by Yeats and Swinburne from Shelley nor the plainer conversational mode that the early Wordsworth bequeathed to Arnold, Hardy, and, later, certain pastoralists and war poets. All registers are understood ironically, as fallen. Indeed, in passages requiring a sudden sense of bare, abject reality, faced honestly and sincerely, without illusions, Eliot will write very plainly. This manipulation of tone is most clear when the consciousness is exposed before the terror of existence, when Eliot is left with only a naked $I:{ }^{33}$

I have seen the moment of my greatness flicker,

And I have seen the eternal Footman hold my coat, and snicker, And in short, I was afraid.

$$
(C P P, 6)
$$

Here I am, an old man ...

But tone is as far as it goes. Behind the Wordsworthian intuition that the plainest words have a special capacity to signify object reality lies a familiar, originary desire that language return to a moment before thought, meaning, the miscellaneous clutter of a fully formed mind.

In "Gerontion" Eliot makes us aware of the clutter, translating it into a prodigious variety of register. In the first verse paragraph alone Eliot moves virtuosically from plain-speaking ("Here I am"), to a higher,

32 Both Pound and Stevens are best understood as poets of consciousness, extending, albeit in very different ways, the Eliotic model and passing those modifications on to their many descendants. In Stevens's long poems we see a consciousness that takes the imagination as its primary (and perhaps only) subject. Pound's Cantos best demonstrates the way that consciousness happens and continues to happen until it stops. As in the very different object poetries of Moore and Williams, the consciousness is an assembler of experience.

33 On the theme of terror in Eliot see Ronald Schuchard, "Eliot and the Horrific Moment," Southern Review 21 (1985): 1045-56. 
vaguely heroic rhetoric ("deep in the salt marsh, heaving a cutlass"), to a mix of invective and bluster ("Spawned in some estaminet of Antwerp"), to a more casual slang ("keeps the kitchen"). Each of these shifts has an effect, yet the cumulative impression is of sameness. A series of discourses with very different sources and normal uses is assimilated to the hum of a more present consciousness, of which all are the object. Thus, when we encounter a catalog that could have been lifted from early Wordsworth, "Rocks, moss, stonecrop, iron . . . ," the effect it makes is not Wordsworthian. Despite the short, concrete nouns, we do not perceive objects in the world so much as objects briefly in the mind of the speaker, then just as quickly gone. In other words, the shift in Eliot's usage is from diction to syntax: the most important thing in his language is not the word, signifying an object of apprehension, but the larger language system, suggesting a frame of mind. ${ }^{34}$ Real things have their place, certainly, but it is subordinate or, more accurately, allegorical. "A tedious argument of insidious intent," indeed: as objects in the speaker's consciousness, as objects of his helpless knowledge, the rocks and stonecrop, the landlord and goat imply a consistent system of meanings, albeit one imperfectly understood by us and possibly incommunicable. ${ }^{35}$

Can consciousness be a good in itself? In the years that Eliot grappled with this question, his verse had a more qualified answer than his prose. "Gerontion," which is almost exactly contemporary with "Tradition and the Individual Talent," is probably the Eliot poem most deeply invested in this problem. The dark view it takes of consciousness is implicit in the first two lines: an old man being read to by a boy. In Wordsworth the child is father to the man; here the man is utterly cut off, not mature, not ripe with age and the amassed wisdom of a long life but, rather, moribund, needing to be read to by an obvious and poor sur-

34 This replacement of diction by syntax is anticipated by Yeats. In "A General Introduction for My Work" he comments: "I tried to make the language of poetry coincide with that of passionate, normal speech. [However] I discovered some twenty years ago that I must seek, not as Wordsworth thought, words in common use, but a powerful and passionate syntax" (Essays and Introductions, 521-22).

35 See Gordon Teskey, Allegory and Violence (Ithaca, N.Y.: Cornell University Press, 1996), 148-67; and Peter Nicholls, Modernisms: A Literary Guide (Berkeley: University of California Press, 1995), 22-25. 
rogate for the normal, developed past he lacks. ${ }^{36}$ Like other Eliot protagonists (Aunt Helen; implicitly the lady in "Portrait of a Lady"), he is the last, frayed end of a genteel line: "My house is a decayed house." As in these and other poems, his tenuous position is accentuated by the presence of ironic, vital underlings (Prufrock's snickering footman, the obscene servants in "Aunt Helen"). Here the most threatening figure is the "jewish" owner. I cannot add much to the discussion of Eliot's antiSemitism, especially in the wake of Anthony Julius's still recent and very thorough study, but I would suggest that Eliot draws on a specific, timehonored topos. ${ }^{37}$ Jews are horrifying not just because they are international (Antwerp, Brussels, London), animalic ("squats"), and capable of copious proliferation ("spawned" is more evocative of salmon than of people). Much worse, they are timeless, and over the centuries they have succeeded materially precisely because of their crude, utterly nonspiritual energy. They are thus a particular insult and threat to Gerontion, who is also an ageless consciousness, who does worry about questions of the spirit ("Signs are taken for wonders. 'We would see a sign!'” [CPP, 21]), yet whose mind is a clutter of events and images, mostly opportunities lost, which finally amount to nothing, mere empty knowledge.

I have purposely limited my analysis to this first verse paragraph. The remainder of the poem is an elaboration of the problem set out here. "After such knowledge, what forgiveness" (CPP, 22): with effort, the speaker considers ways that consciousness might lead to something transcendent. Aestheticism ("Hakagawa, bowing among the Titians"), Yeatsian spiritualism ("Madame de Tornquist, in the dark room / Shifting the candles") $(C P P, 22)$, and finally pure sensuality are considered, only to be dismissed:

These with a thousand small deliberations

Protract the profit of their chilled delirium,

Excite the membrane, when the sense has cooled,

With pungent sauces, multiply variety

In a wilderness of mirrors.

(CPP, 23)

${ }^{36}$ See Anthony Julius's reading of these details in T. S. Eliot, Anti-Semitism, and Literary Form (Cambridge: Cambridge University Press, 1995), 41-49.

${ }^{37}$ See also Christopher Ricks's defense in T. S. Eliot and Prejudice (London: Faber and Faber, 1988), 25-76. 
In Julius's trenchant phrase, "There is neither revelation nor development, the poem withholding such possibilities" (41). If "Gerontion," in the end, answers the question "Can consciousness be a good in itself?" affirmatively, it is with the barest adequacy. Neither the intense, unrequited longing at the end of The Waste Land nor the spiritual despair of "The Hollow Men" varies in this answer. "Gerontion" tries to offer a knowledge without illusions. In a manner of speaking, it is sincere: "I would meet you upon this honestly" (CPP, 22). The poem aspires, in a spirit of meagerness, to be "part of the consciousness of an age which cannot be understood apart from [it]." This is not, however, the kind of affirmation Eliot would wish to sustain. Nor did he, though during the years of his greatest influence on subsequent poets, from the $1910 \mathrm{~s}$ to 1927 , when his entering the Anglican Church offered a final no to that question, he sustained the attempt.

\section{Postscript}

Modern poetry was never young. In its old age modern poetry occasionally regretted the oversight. In Eliot at twenty, as in Yeats at fifty, the polemical rejection of any developmental understanding of self required both a forceful insistence on the poet's own maturity and a concealment of his past. Both men would come to feel the loss. We see it in late, retrospective Yeats poems like "Under Ben Bulben" and "The Municipal Gallery Revisited," as well as in works of veiled autobiography like "A Prayer for My Daughter." Eliot's career arc is not so different. In the thirties and forties the erstwhile apostle of impersonality ventures increasingly into reminiscence. In "The Dry Salvages" and "Landscapes" he revisits the world of his childhood. More shocking, he dismantles much of the critical apparatus he developed to explain his earlier work. He disavows the doctrine of impersonality itself, with astounding (though unintended) irony, as immature:

I have, in early essays, extolled what I called impersonality in art. . . . It may be that I expressed myself badly, or that I had only an adolescent grasp of that idea ... but I think now, at least, that the truth of the matter is as follows. There are two forms of impersonality: that which is natural to the mere skilful craftsman, and that which is more and more achieved by the maturing artist.... The second impersonality is that of 
the poet who, out of intense personal experience, is able to express a general truth; retaining all the particularity of his personal experience, to make of it a general symbol. $\left(S P, 25^{1}\right)$

And where does this "intense personal experience" come from? Eliot, who pointedly took issue with Wordsworth's formula "emotion recollected in tranquility," has a ready answer:

I suggest that what gives [a great poet's imagery] such intensity as it has in each case is its saturation . . . but with feelings too obscure for the autho[r] even to know quite what they were. ... It comes from the whole of his sensitive life since early childhood. Why, for all of us, out of what we have heard, seen, felt, in a lifetime, do certain images recur, charged with emotion, rather than others? [A list of such images follows]: such memories may have symbolic value, but of what we cannot tell, for they come to represent the depths of feeling into which we cannot peer. $(S P, 91)$

Intense experiences of childhood, powerfully resonant images, whose meanings are nevertheless veiled from the poet by his distance from their source: late in life, long after the period that produced "Convictions" and "Gerontion," the psychology of poetic power and the nature of the imagination, as understood by Eliot, sound most of all like Wordsworth.

It is a shocking reversal, yet wholly understandable: Eliot's attack on Wordsworth and turn to a poetry of consciousness were very much the strategies of a young man uncomfortable with his background and eager to demonstrate his sophistication. Psychology was a threat, a middle-class vulgarity, an inquiry into origins better left hidden. These strategies served their purpose, but it is entirely natural that, later in life, having achieved success and stature, the same man should wish to, as it were, claim responsibility for his own early success: to recognize the imagination where he once saw only a pained and passive consciousness, to reclaim the anonymous as personal. In later Eliot childhood experience assumes a place, albeit tentative and often spectral; the past, finally, is a special preserve, separate from the adult identity Eliot created for himself, yet glimpsed fitfully, with only partial comprehension, at telling moments. For Eliot, becoming modern meant renouncing his past; recovering that past was a later step in becoming Eliot. 